\title{
Spatio-Temporal Analysis of Meteorological Elements in the North China District of China during 1960-2015
}

\author{
Jinsong Ti ${ }^{1,2}$, Yuhao Yang ${ }^{1,2}$, Xiaogang Yin ${ }^{1,2}$, Jing Liang ${ }^{3}$, Liangliang Pu ${ }^{1,2}$, Yulin Jiang ${ }^{1,2}$, \\ Xinya Wen ${ }^{1,2}$ and Fu Chen ${ }^{1,2, *}$ \\ 1 College of Agronomy and Biotechnology, China Agricultural University, Yuan-Ming-Yuan West Road 2, \\ Haidian, Beijing 100193, China; tijinsong@cau.edu.com (J.T.); yyh19961221@163.com (Y.Y.); \\ yinxg@cau.edu.cn (X.Y.); 15093521136@163.com (L.P.); jiangyulin93@163.com (Y.J.); wxya@cau.edu.cn (X.W.) \\ 2 Key Laboratory of Farming system, Ministry of Agriculture and Rural Affairs of the People's Republic of \\ China, Yuan-Ming-Yuan West Road 2, Haidian, Beijing 100193, China \\ 3 Department of Environmental Sciences, University of California, 900 University Ave, \\ Riverside, CA 92521, USA; jing.liang@email.ucr.edu \\ * Correspondence: chenfu@cau.edu.cn; Tel.: +86-10-6273-3316
}

Received: 24 May 2018; Accepted: 11 June 2018; Published: 15 June 2018

\begin{abstract}
The North China District (NCD) is one of the main grain production regions in China. The double cropping system of irrigation has been leading to the groundwater table decline at the speed of 1-2 m per year. Climate change leads to uncertainty surrounding the future of the NCD agricultural system, which will have great effects on crop yields and crop water demands. In this research, the Meteorological dataset from 54 weather station sites over the period 1960-2015 were collected to quantify the long-term spatial and temporal trends of meteorological data, including daily minimum temperature $\left(\mathrm{T}_{\min }\right)$, maximum temperature $\left(\mathrm{T}_{\max }\right)$, precipitation, solar radiation, reference evapotranspiration $\left(\mathrm{ET}_{0}\right)$, and aridity index $(\mathrm{AI})$. The results show that the long-term wheat and maize growing season and annual average air temperatures $\left(T_{\min }\right.$ and $\left.T_{\max }\right)$ showed strong north to south increasing trends throughout the NCD. The average annual precipitation was $632.9 \mathrm{~mm}$ across the NCD, more than $70 \%$ of which was concentrated in the maize growing season. The regional average annual $\mathrm{ET}_{0}$ was $1026.1 \mathrm{~mm}$, which was 531.2 and $497.4 \mathrm{~mm}$ for the wheat and maize growing season, respectively. The regional precipitation decreased from northwest to southeast in each growing season and annual timescale. The funnel areas have lower precipitation and higher $\mathrm{ET}_{0}$ than the regional average, which may lead to the mining of the groundwater funnel area. The regional average annual $\mathrm{AI}$ is 0.63 , which lies in the humid class. For temporal analysis, the regional average trends in annual $\mathrm{T}_{\min }, \mathrm{T}_{\max }$, solar radiation, $\mathrm{ET}_{0}$, precipitation, and $\mathrm{AI}$ were $0.37^{\circ} \mathrm{C} / 10 \mathrm{a}, 0.15^{\circ} \mathrm{C} / 10 \mathrm{a},-0.28 \mathrm{MJ} /$ day $/ \mathrm{m}^{2} / 10 \mathrm{a},-2.98 \mathrm{~mm} / 10 \mathrm{a},-12.04 \mathrm{~mm} / 10 \mathrm{a}$, and $0.005 / 10 \mathrm{a}$, respectively. The increasing trend of temperature and the decreasing trend of solar radiation may have a negative effect on the regional food security. The funnel area AI showed a significant increasing trend for the winter wheat growing season and a decreasing trend for maize, which indicated that more irrigation will be needed for the maize growing season and the winter fallow policy may lead to the increasing trend precipitation being wasted. Analyzing the growing season and the annual meteorological elements of the spatiotemporal trends can help us better understand the influence of climate change on the natural resources and agricultural development in both the past and the future, and will provide us with invaluable information for the modification of cropping patterns to protect the regional and national water and food security.
\end{abstract}

Keywords: climate change; trend analysis; climate variables; water security; North China District 


\section{Introduction}

Global warming, becoming a real and pressing problem, is accepted widely as the main feature of climate change. The Fifth Assessment Report of the United Nations Intergovernmental Panel on Climate Change [1] showed that the period of 1983-2012 was the warmest 30 years over the last 800 years for the average annual Northern Hemisphere temperatures. Climate change has a great effect on the water demand of plants and crops, the water consumption, and the grain yield due to increased temperatures and variable rainfall, especially in poor adaptability areas [2,3]. Climate change is expected to increasingly affect crop yields [4-8] and crop water requirements [9]; which impact on the regional and global food security and water security.

The North China District (NCD) is one of the most important grain producing areas in China. It produces $7.31 \times 10^{7}$ ton of wheat and $5.73 \times 10^{7}$ ton of maize with $1.17 \times 10^{7}$ ha and $10.00 \times 10^{7}$ ha area, which was $56.7 \%$ of the nation's wheat yields and $26.1 \%$ of its maize yields [10]. Thus, NCD plays an important part in ensuring China's food security. The winter wheat-summer maize cropping system is the main cropping system in the North China District. This double cropping system needs about 800-1100 mm water every year [11], while the average annual precipitation is around 500-600 $\mathrm{mm}$ at the same time [12], thus, irrigation is needed in order to meet the optimal yield. However, the water resources are limited in this area and most of the irrigation water was from underground water, which causes a dramatic decline of the water table. In addition, irrigation is related to the distribution of the precipitation crop water requirement. Thus, assessing the spatiotemporal changes of the data is beneficial for optimizing irrigation during the wheat-maize cropping system and regional food and water security.

In the context of global warming, the trend of the temperature was found to have increased for most of the world [13-15]. While the solar radiation [16], precipitation [17,18], ET0 [19], and AI [20,21] were found to have increased or decreased in different regions of the world. Earlier regional studies that performed a trend analysis of the meteorological elements are more focused on one climate element in an annual timescale. However, crops are affected differently by the meteorological elements in different growing seasons. Therefore, assessing meteorological element trends both spatially and temporally in different growing seasons and with an annual timescale may help us better understand how climate change impacts regional food and water security. The aims of the present study are: (1) to analyze the spatial meteorological elements in different growing seasons and with annual timescale; (2) to calculate the meteorological element trends in different growing seasons and with an annual timescale; (3) to discuss the possible impacts of climate change on the regional water and food security of NCD.

\section{Materials and Methods}

\subsection{Study Area Description}

This study area consists of five provinces and cities (Beijing, Tianjin, Hebei, Shandong, Henan), which is a generally similar area to the North China Plain (Figure 1). The region is located between the longitude of 31 and $43^{\circ} \mathrm{N}$ and it is a monsoon climate with medium latitudes. The annual precipitation is around an average value of 500 to $600 \mathrm{~mm}$ [22]. In this study, each year was divided into two periods, comprising the winter wheat growing season and the summer maize growing season. Generally, the winter wheat growing season is from October to June and the summer maize growing season is from July to September. 


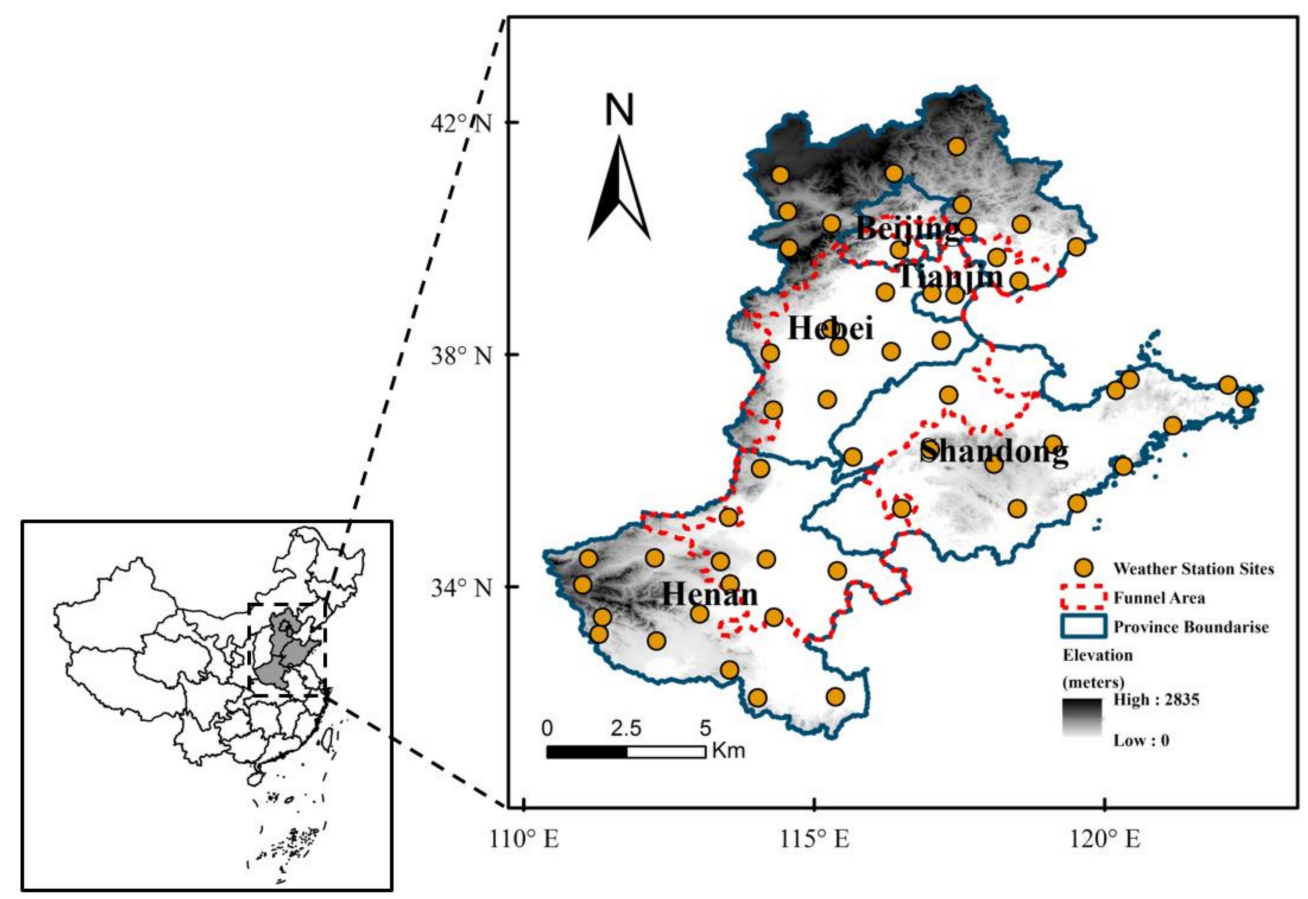

Figure 1. Location of North China District and the weather station site.

\subsection{Input Data Sources}

The daily meteorological data from 54 weather station sites across the NCD contains the maximum air temperature, minimum air temperature, average relative humidity, precipitation, bright sunshine hours, and wind speed, which were obtained from the China Meteorological Data Sharing Service System. Most selected weather stations possess data from 1960 to 2015. The Mengjin, Qingdao, and Changdao weather stations possess data from 1961 to 2015, and the Weihai station, from 1940 to 2015 (Figure 1). The groundwater contiguous groundwater funnel area is collected from the Announcement of Outlaws Area, Restricted Area, and Prohibited Area of each province.

\subsection{Calculation of $E T_{0}$ and Aridity Index}

Reference crop evapotranspiration $\left(\mathrm{ET}_{0}\right)$ expresses the evaporating power of the atmosphere at a specific location and period. $\mathrm{ET}_{0}$ is a climate parameter and is only affected by climate parameters. There are many equations to estimate $\mathrm{ET}_{0}$, such as the Hargreaves Equation [23], Priestley-Taylor Equation [24], Penman-Monteith Equation [25], and FAO Penman-Monteith Equation [26]. In this study, we use the FAO Penman-Monteith Equation, which was most widely used to estimate the $\mathrm{ET}_{0}$ around the world. The FAO Penman-Monteith Equation can be expressed as:

$$
\mathrm{ET}_{0}=\frac{0.408 \triangle\left(R_{n}-G\right)+\gamma \frac{900}{T+273} \mu_{2}\left(e_{s}-e_{a}\right)}{\triangle+\gamma\left(1+0.34 \mu_{2}\right)}
$$

where $R n$ is the net radiation at the crop surface $\left(\mathrm{MJ} / \mathrm{m}^{2} /\right.$ day), which was calculated from the sunshine hours using the equation developed by Rietveld [27]; $G$ is the soil heat flux density $\left(\mathrm{MJ} / \mathrm{day} / \mathrm{m}^{2}\right)$; $T$ is the air temperature at a $2 \mathrm{~m}$ height $\left({ }^{\circ} \mathrm{C}\right) ; \mu_{2}$ is the wind speed at a $2 \mathrm{~m}$ height $(\mathrm{m} / \mathrm{s}) ; e_{S}$ is the saturation vapor pressure $(\mathrm{kPa}) ; e_{a}$ is the actual vapor pressure $(\mathrm{kPa}) ; \Delta$ is the slope of the saturation vapor pressure-temperature curve $\left(\mathrm{kPa} /{ }^{\circ} \mathrm{C}\right)$; and $\gamma$ is the psychometric constant $\left(\mathrm{kPa} /{ }^{\circ} \mathrm{C}\right)$. $\mathrm{The}_{0}$ was calculated by the SIMETAW model, which was developed based on the FAO Penman-Monteith equation [28], and has widely used in NCD [29-32].

Aridity Index (AI) is an index for assessing drought risk in the crop growing period, which considers the total precipitation and evapotranspiration. There are many methods to evaluate 
an AI. In this research, the AI was calculated according to the UNESCO [33] method, which can be computed as

$$
\text { Aridity index }(\mathrm{AI})=\frac{P}{\mathrm{ET}_{0}}
$$

where $P$ is the precipitation $(\mathrm{mm})$ that is obtained from each weather station site. The annual $P$ and $\mathrm{ET}_{0}$ of the winter-wheat and summer-maize growing season is obtained by summing the daily $\mathrm{ET}_{0}$ rasters. Any site can be classified into the five categories of hyper-arid, arid, semi-arid, dry-subhumid, and humid according to the magnitude of the AI, which is classified by the numeric $0.03,0.2,0.5$ and 0.65 .

\subsection{Mann-Kendall Trend Test and Slop Estimator}

The Mann-Kendall (M-K) is one of the widely used non-parametric tests for detecting significant trends and slope in time series [34,35]. There are many methods to detect the significant trend of the considered meteorological elements in time series of the selected stations, the Mann-Kendall and Spearman's Rho test are most widely used. Many theses have discussed the difference between the Mann-Kendall and Spearman's Rho test [36-38], the results show a similar performance of these two methods. In this study we used the M-K method to detect the significant trend and Sen's method to detect trend magnitudes, which were suggested by the World Meteorological Organization [39]. The advantage of the Mann-Kendall trend test is that it is not contaminated by a small number of outliers and the sample does not need to rank within a certain distribution, so it is widely used to estimate streamflow, precipitation, and temperature trend. The M-K test statistic $\mathrm{S}$ is calculated as

$$
\mathrm{S}=\sum_{i=1}^{n-1} \sum_{j=i+1}^{n} \operatorname{sgn}\left(x_{j}-x_{i}\right)
$$

where $n$ is the number of data points, $x_{i}$ and $x_{j}$ are the data values in the time series $i$ and $j(j>i)$, respectively, and $\operatorname{sgn}\left(x_{j}-x_{i}\right)$ is the sign function as

$$
\operatorname{sgn}\left(x_{j}-x_{i}\right)=\left\{\begin{array}{l}
+1, \text { if } x_{j}-x_{i}>0 \\
0, \text { if } x_{j}-x_{i}=0 \\
-1, \text { if } x_{j}-x_{i}>0
\end{array}\right.
$$

The variance is computed as

$$
\operatorname{Var}(S)=\frac{n(n-1)(2 n+5)-\sum_{i=1}^{m} t_{i}\left(t_{i}-1\right)\left(2 t_{i}+5\right)}{18}
$$

where $n$ is the number of data points, $m$ is the number of tied groups, and $t_{i}$ denotes the number of ties of extent $i$. A tied group is a set of sample data having the same value. In cases where the sample size $n>10$, the standard normal test statistic $Z_{S}$ is computed as

$$
Z_{S}= \begin{cases}\frac{S-1}{\sqrt{\operatorname{Var}(S)}}, & \text { if } S>0 \\ 0, & \text { if } S=0 \\ \frac{S-1}{\sqrt{\operatorname{Var}(S)}}, & \text { if } S<0\end{cases}
$$

Positive values of $Z_{S}$ indicate increasing trends while negative $Z_{S}$ values show decreasing trends. The testing trends are done at the specific $\alpha$ significance level. When $\left|Z_{S}\right|>Z_{(1-\alpha 2)}$, the null hypothesis is rejected and a significant trend exists in the time series. $Z_{(1-\alpha / 2)}$ is obtained from the standard normal distribution table. In this study, a significance level of $\alpha=0.05$ was used. At the $5 \%$ significance level, the null hypothesis of no trend is rejected if $\left|Z_{S}\right|>1.96$. 
Sen's slope estimator [40] can be used for estimating time series data trend magnitudes. The advantage of this method is that it limits the influence of the outliers on the slope in comparison with linear regression. This estimate is given by the Theil-Sen Estimator as

$$
\mathrm{b}=\operatorname{Median}\left(\frac{x_{j}-x_{z}}{j-1}\right)
$$

where $x_{j}$ and $x_{z}$ are the data values at times $j$ and $z(j>z)$, respectively; $\mathrm{b}$ denotes the annual increment under the hypothesis of a linear trend. $b$ provides the real slope of the tendency and can vary slightly from the slope obtained from linear regression. Sen's slope estimator is widely used to estimate the magnitudes of trends in the climatic factors.

In this study, the $\mathrm{M}-\mathrm{K}$ test is used to analyze the trends of air temperature, daily temperature range, solar radiation, precipitation, $\mathrm{ET}_{0}$, and $\mathrm{AI}$ in the $\mathrm{NCD}$. The $\mathrm{M}-\mathrm{K}$ trend test and slop estimator of each weather station site is calculated by MATLAB R2017b.

\section{Results}

\subsection{Spatial and Temporal Variation of Temperature}

\subsubsection{Spatial Analysis}

The temperature significantly influences crop yields and crop water use. Global warming has increased the instability of agriculture and the fluctuation of crop yields. The increase in temperature has delayed autumn frosts and led to later sowing and earlier harvesting of the winter-wheat growing season in the North China District [41]. Moreover, higher daily maxim temperatures have also caused heat and drought stress during the wheat and maize growing season, which highly negatively affected the crop yields [2,42-44]. On the other hand, higher daily minimum temperatures have accelerated the respiration of crops, which thus, have caused yield loss. Furthermore, temperature is one of the important input data for many hydrology and crop models. Thus, it is necessary to evaluate the regional temperature trend both spatially and temporally.

During 1960-2015, the average daily minimum temperature $\left(\mathrm{T}_{\min }\right)$ was lower in the north compared to the south through the wheat and maize growing season (Figure 2a-c). The figure indicates that the average daily $\mathrm{T}_{\min }$ of the maize growing season is higher than wheat, which was above zero over the study area. The wheat and maize growing season $\mathrm{T}_{\min }$ ranged from -9.0 to $6.6^{\circ} \mathrm{C}$ and from 10.3 to $22.1{ }^{\circ} \mathrm{C}$; and from -2.6 to $11.8^{\circ} \mathrm{C}$ when averaged annually. The average daily $\mathrm{T}_{\min }$ of the Henan province is the highest, which is $4.6,20.3$, and $9.8^{\circ} \mathrm{C}$ for wheat, the maize growing season, and annually; the Hebei province was the lowest (Table 1). Similar to $\mathrm{T}_{\min }$, the Hebei and Henan provinces are the highest and lowest $T_{\max }$ for the three periods. The average daily maximum air temperature $\left(T_{\max }\right)$ of the study region has a south-to-north decreasing trend for the wheat growing season and annually, ranging from -2.6 to $11.5^{\circ} \mathrm{C}$ and 3.7 to $16.2^{\circ} \mathrm{C}$. Unlike the wheat growing stage, the $\mathrm{T}_{\max }$ for maize has shown a middle-surround decreasing trend in the NPD, which ranged from 22.3 to $30.6^{\circ} \mathrm{C}$.

Table 1. The province-wide, funnel area and regional statistics for wheat, maize, and the annual temperature.

\begin{tabular}{cccccccc}
\hline & Beijing & Tianjin & Hebei & Henan & Shandong & Funnel Area & Regional \\
\hline $\mathrm{T}_{\min }$ & & & & & & & \\
Wheat growing season & 1.3 & 2.7 & -1.2 & 4.6 & 2.8 & 2.4 & 1.9 \\
Maize growing season & 19.3 & 20.9 & 17.4 & 20.3 & 19.3 & 19.9 & 19.0 \\
Annual & 7.3 & 8.8 & 5.0 & 9.8 & 8.3 & 8.2 & 7.6 \\
\hline $\mathrm{T}_{\max }$ & & & & & & & \\
Wheat growing season & 12.3 & 11.8 & 10.8 & 15.1 & 11.8 & 13.5 & 12.5 \\
Maize growing season & 29.4 & 28.9 & 28.2 & 29.9 & 27.3 & 29.9 & 28.6 \\
$\quad$ Annual & 18.0 & 17.5 & 16.6 & 20.1 & 17.0 & 18.9 & 17.8 \\
\hline
\end{tabular}




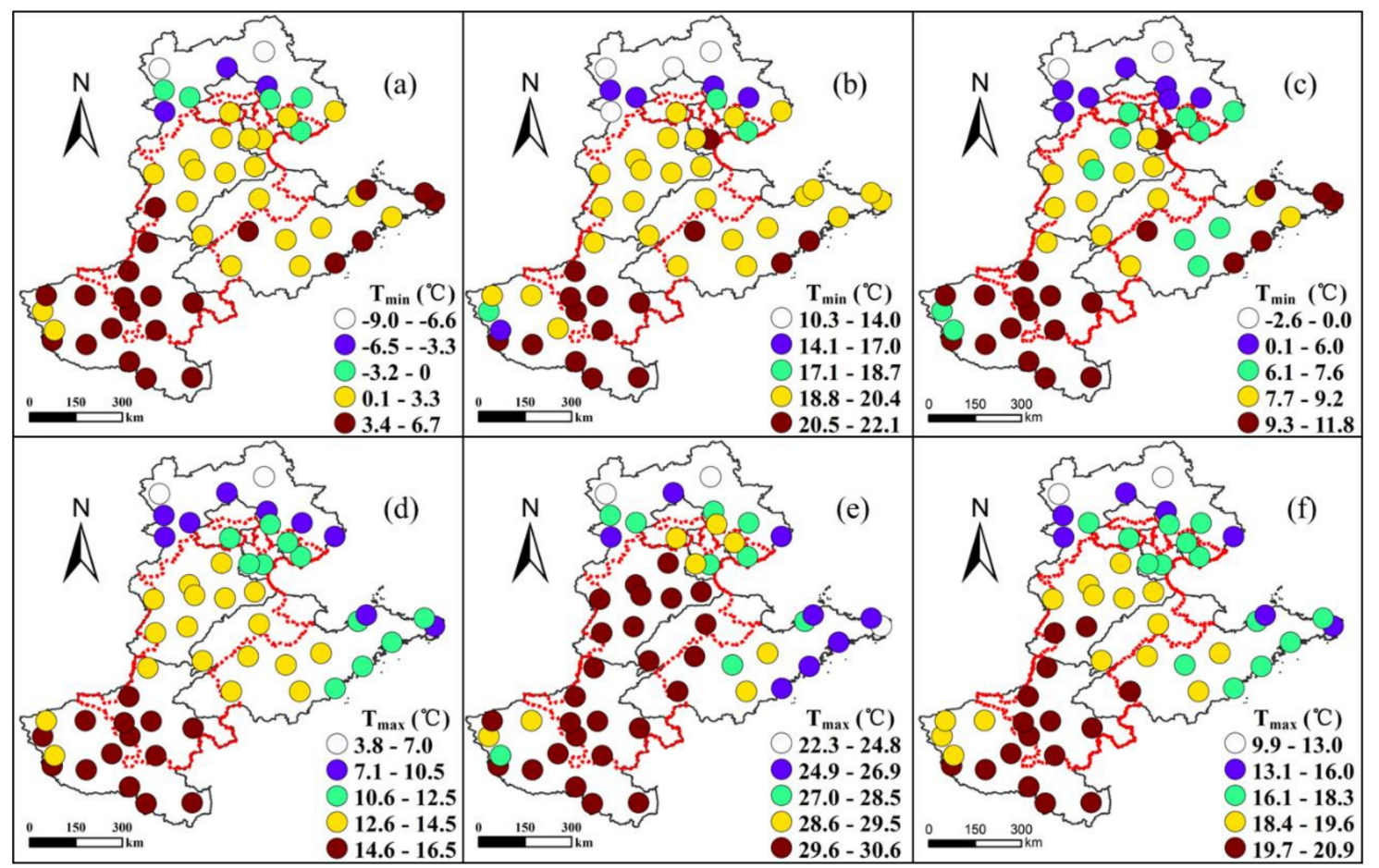

Figure 2. The spatial distribution of $(\mathbf{a}-\mathbf{c})$ long-term average minimum air temperature $\left(\mathrm{T}_{\min }\right)$ and $(\mathbf{d}-\mathbf{f})$ maximum air temperature $\left(\mathrm{T}_{\max }\right)$ on the winter-wheat growing season, summer-maize growing season, and annual basis.

\subsubsection{Temporal Analysis}

The trends in the winter-wheat, summer-maize growing season, and the annual timescale from 1961 to 2015 for $\mathrm{T}_{\min }$, and $\mathrm{T}_{\max }$ are shown in Figure 3. The maps also show the statistical significance of the weather station trends during the research period. The different color circles indicate the value of the temporal trends and the positive and negative numbers represent the increasing and decreasing trend. The black points in the maps indicate that the trend quantified for the weather station was statistically significant at $\alpha=0.05$, while the red rose point represents the significance of the increasing trends, which distinguishes them from the station with insignificant trends that are assigned with a white point. Table 2 shows the trend statistics for the growing seasons and the annual timescale $T_{\min }$ and $T_{\min }$ on a province-wide, funnel, and regional basis. Figure $3 \mathrm{a}-\mathrm{c}$ show that most of the study regions show significant increasing trends in the wheat and maize growing seasons and the annual $\mathrm{T}_{\min }$. Only one weather station shows a decreasing trend in the winter-wheat growing season and the annual timescale. It was higher in the wheat growing season than in the maize growing season, with the highest $\mathrm{T}_{\min }$ trend province being Beijing in the wheat growing season (Table 2). The regional average increasing trends in the wheat and maize growing seasons and the annual $\mathrm{T}_{\min }$ were $0.44,0.24$, and $0.37^{\circ} \mathrm{C} / 10 \mathrm{a}$, respectively. Like $\mathrm{T}_{\min }$, the trends for both the winter-wheat growing season and the annual timescale $\mathrm{T}_{\max }$ were positive, while the central parts of the NCD show non-significant increasing trends for the wheat growing season and the annual timescale (Figure $3 \mathrm{~d}-\mathrm{f}$ ). On the other hand, the main parts of the Henan province show decreasing trends for the maize growing season, which was different to the $T_{\min }$. Table 2 shows that the average $\mathrm{T}_{\max }$ in the Henan province for the maize growing season is the only decreasing growing season $\mathrm{T}_{\max }$, province-wide, which was $-0.08{ }^{\circ} \mathrm{C} / 10 \mathrm{a}$. 
Table 2. The province-wide, funnel area, and regional statistics for the wheat, maize, and annual temperature trends.

\begin{tabular}{|c|c|c|c|c|c|c|c|}
\hline & Beijing & Tianjin & Hebei & Henan & Shandong & Funnel Area & Regional \\
\hline \multicolumn{8}{|l|}{$\mathrm{T}_{\min }\left({ }^{\circ} \mathrm{C} / 10 \mathrm{a}\right)$} \\
\hline Wheat growing season & $0.68 *$ & $0.26^{*}$ & $0.53 *$ & $0.37 *$ & $0.41 *$ & $0.53 *$ & 0.44 \\
\hline Maize growing season & $0.53 *$ & 0.14 * & $0.32 *$ & $0.17^{*}$ & $0.21 *$ & $0.28 *$ & 0.24 \\
\hline Annual & $0.64 *$ & $0.22 *$ & $0.46^{*}$ & 0.30 * & 0.34 * & $0.42 *$ & 0.37 \\
\hline \multicolumn{8}{|l|}{$\mathrm{T}_{\max }\left({ }^{\circ} \mathrm{C} / 10 \mathrm{a}\right)$} \\
\hline Wheat growing season & $0.25 *$ & $0.36^{*}$ & $0.23 *$ & $0.23 *$ & 0.24 * & 0.20 * & 0.23 \\
\hline Maize growing season & $0.19 *$ & $0.23 *$ & $0.12 *$ & -0.08 & 0.08 & 0.02 & 0.04 \\
\hline Annual & $0.25 *$ & $0.32 *$ & 0.17 * & $0.10 *$ & 0.18 * & 0.11 * & 0.15 \\
\hline
\end{tabular}

${ }^{*}$ Indicates that the temporal trend is significant $(p<0.05)$.

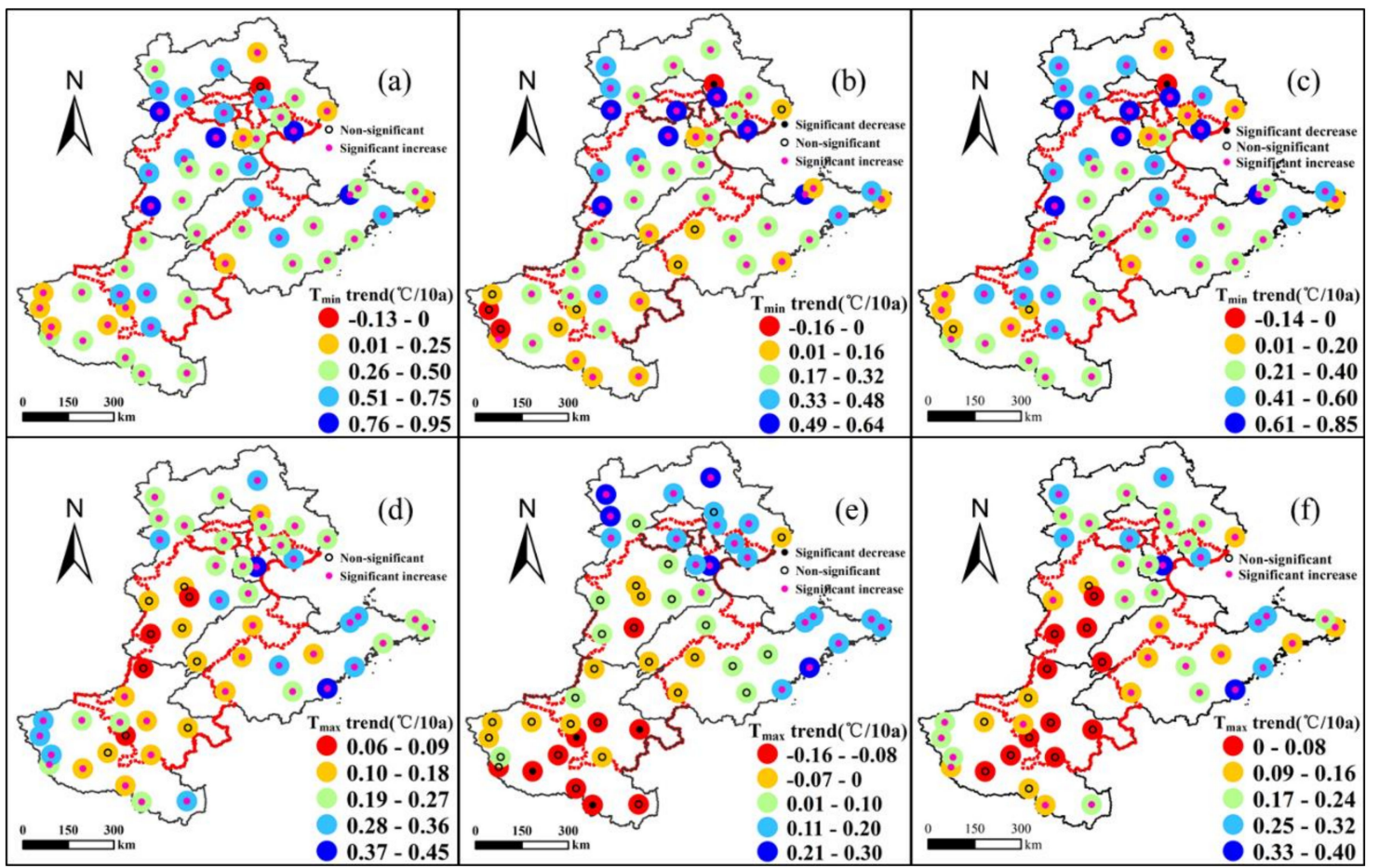

Figure 3. The spatial distribution and statistical significance of the trends in (a-c) $T_{\min }$ and $(\mathbf{d}-\mathbf{f}) \mathrm{T}_{\max }$ on the winter-wheat growing-season, the summer-maize growing-season, and the annual basis.

\subsection{Spatial and Temporal Variation of Solar Radiation}

\subsubsection{Spatial Analysis}

Solar radiation is the most important source of renewable and environmental energy on the planet. Because of its abundance, solar energy can play a prominent role in our future energy and reduce the dependency on fossil fuel. In addition, many researchers have discovered the importance and positive effect of solar radiation on crop yield [45,46]. During 1960 to 2015, the average daily solar radiation was higher in the north compared to the south for the wheat and maize growing seasons and the annual timescale. It varied between 12.5 and $14.9 \mathrm{MJ} /$ day $/ \mathrm{m}^{2}$ in the wheat growing season (Figure $4 \mathrm{a}$ ), which was lower than the maize growing season (Figure $4 \mathrm{~b}$ ). Table 3 shows the descriptive statistics for the average daily solar radiation. The Shandong province had the highest solar radiation for the wheat growing season from the five provinces. While, for maize growing season, the Tianjin and Hebei provinces were the highest. There was little difference in the funnel area and regional average daily solar radiation. 


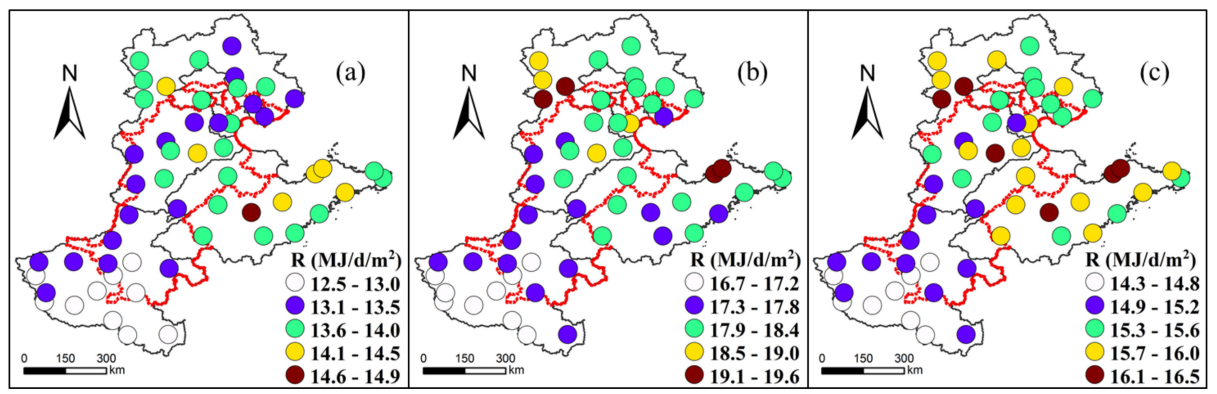

Figure 4. The spatial distribution of the long-term average daily solar radiation (R) for (a) the winter-wheat growing season; (b) the summer-maize growing season and (c) the annual basis.

Table 3. The province-wide, funnel area, and regional statistics for wheat, maize, and the annual average daily solar radiation.

\begin{tabular}{cccccccc}
\hline $\mathbf{R}\left(\mathbf{M} \mathbf{J} / \mathrm{day} / \mathbf{m}^{\mathbf{2}}\right)$ & Beijing & Tianjin & Hebei & Henan & Shandong & Funnel Area & Regional \\
\hline Wheat growing season & 13.6 & 13.4 & 13.6 & 12.9 & 14.0 & 13.4 & 13.5 \\
Maize growing season & 18.0 & 18.2 & 18.2 & 17.1 & 18.1 & 17.7 & 17.8 \\
Annual & 15.5 & 15.5 & 15.6 & 14.7 & 15.8 & 15.3 & 15.4 \\
\hline
\end{tabular}

\subsubsection{Temporal Analysis}

Most of the NCD daily solar radiation shows a significant decreasing trend for the wheat growing season, except for the west part of the Henan province where the Qinling Mountains exist (Figure 5a). All weather station solar radiation showed significant decreasing trends for the maize growing season, which varied between -0.87 and $-0.16 \mathrm{MJ} /$ day $/ \mathrm{m}^{2} / 10$ a (Figure $5 \mathrm{~b}$ ). All provincial solar radiation showed significant decreasing trends for the wheat and maize growing seasons and the annual timescale. The tendency of the maize growing season was higher than that of the wheat growing season and the funnel area was higher than the regional scale for both the wheat and maize growing seasons (Table 4). The annual solar radiation decreased during 1960 to 2015 at a rate of -0.35 and $-0.28 \mathrm{MJ} / \mathrm{day} / \mathrm{m}^{2} / 10 \mathrm{a}$ in the funnel area and the regional basis, respectively.

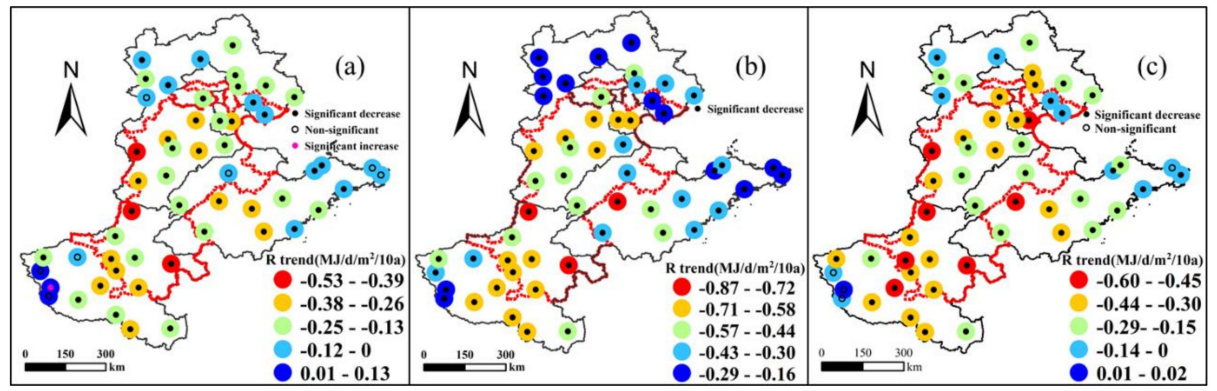

Figure 5. The spatial distribution and statistical significance of the trends in the daily solar radiation (R) on (a) the winter-wheat growing season; (b) the summer-maize growing season and (c) annual basis.

Table 4. The province-wide, funnel area, and regional statistics for the wheat, maize, and annual daily solar radiation average trends.

\begin{tabular}{cccccccc}
\hline $\mathbf{R}\left(\mathbf{M J} / \mathrm{day} / \mathbf{m}^{\mathbf{2}} / \mathbf{1 0 a}\right)$ & Beijing & Tianjin & Hebei & Henan & Shandong & Funnel Area & Regional \\
\hline Wheat growing season & $-0.18^{*}$ & $-0.28^{*}$ & $-0.19^{*}$ & $-0.20^{*}$ & $-0.20^{*}$ & $-0.25^{*}$ & $-0.20^{*}$ \\
Maize growing season & $-0.54^{*}$ & $-0.65^{*}$ & $-0.42^{*}$ & $-0.58^{*}$ & $-0.4^{*}$ & $-0.56^{*}$ & $-0.48^{*}$ \\
Annual & $-0.30^{*}$ & $-0.43^{*}$ & $-0.26^{*}$ & $-0.33^{*}$ & $-0.26^{*}$ & $-0.35^{*}$ & $-0.28^{*}$ \\
\hline
\end{tabular}

${ }^{*}$ Indicates that the temporal trend is significant $(p<0.05)$. 


\subsection{Spatial and Temporal Variation of Precipitation}

\subsubsection{Spatial Analysis}

The quantification of the precipitation spatiotemporal variability in any region is important to enhance the capacity and level of the agriculture drought monitoring, prediction, and impact assessment, especially in arid and semi-arid regions such as NCD where the groundwater table declines by 1-2 m per year [47]. During the period of 1960-2015, the average precipitation decreased from the northwest to the southeast in each of the growing seasons and the annual timescale (Figure 6). The descriptive statistics of the winter-wheat and summer-maize growing seasons and the annual precipitation for the province-wide area are presented in Table 5. Regionally, the wheat growing season precipitation varies from 83.2 to $461.6 \mathrm{~mm}$, which, for the maize growing season and the annual timescale, was from 297.2 to $609.0 \mathrm{~mm}$ and 380.6 to $1070.0 \mathrm{~mm}$, respectively. Averaged by province, the valley wheat and maize growing season precipitations were observed in Beijing and Hebei, respectively, while the maximum values were observed in Henan and Shandong. The minimum value annual precipitation was observed in Hebei too, which was $520.7 \mathrm{~mm}$, while the peak annual precipitation was observed in the Henan province. The regional mean precipitation was $632.9 \mathrm{~mm}$, while for the funnel area, it was $570.4 \mathrm{~mm}$.

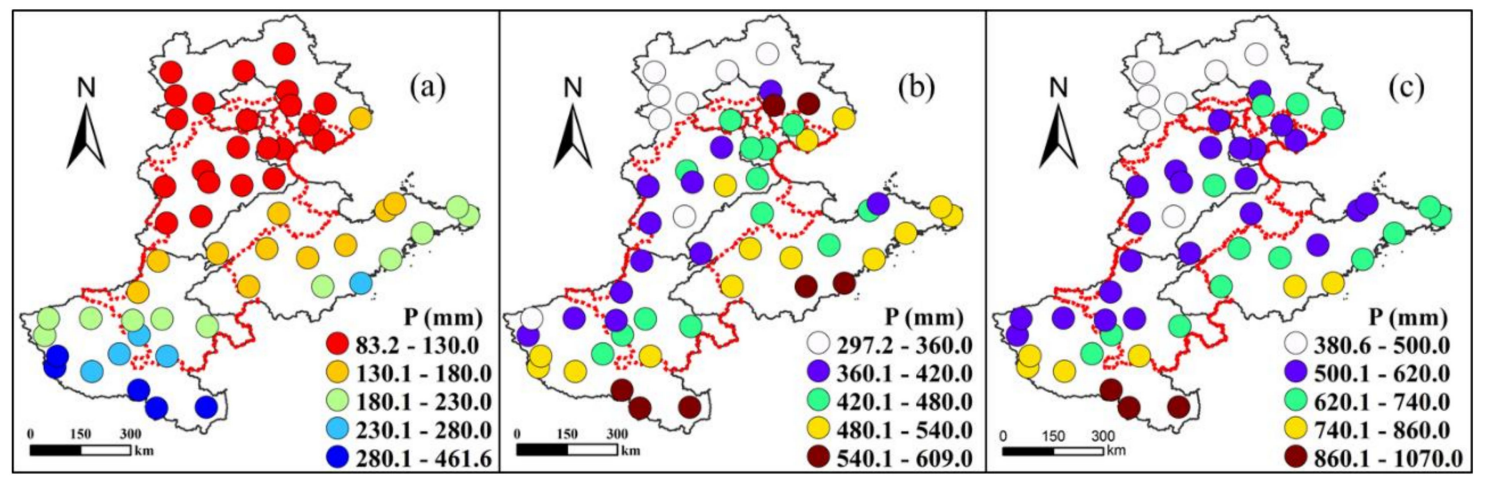

Figure 6. The spatial distribution of the long-term average precipitation $(\mathrm{P})$ for $(\mathrm{a})$ the winter-wheat growing season; (b) the summer-maize growing season and (c) the annual basis.

Table 5. The province-wide, funnel area, and regional statistics for the wheat, maize, and annual average precipitations.

\begin{tabular}{cccccccc}
\hline P $(\mathbf{m m})$ & Beijing & Tianjin & Hebei & Henan & Shandong & Funnel Area & Regional \\
\hline Wheat growing season & 99.7 & 109.8 & 108.3 & 260.8 & 185.6 & 138.7 & 176.4 \\
Maize growing season & 445.3 & 441.4 & 412.5 & 470.7 & 507.4 & 431.7 & 458.0 \\
Annual & 545.0 & 551.2 & 520.7 & 730.8 & 688.1 & 570.4 & 632.9 \\
\hline
\end{tabular}

\subsubsection{Temporal Analysis}

The trends in the winter-wheat and summer-maize growing seasons and the annual precipitation have been computed for the period 1960-2015 using a non-parametric test (Figure 7). The winter-wheat growing season precipitation trends are positive for the study area and more than $44.4 \%$ of the weather station showed a significant increase. As shown in Figure 7a, the trend of the precipitation was higher in the east of the NCD than the west. Unlike the wheat growing season precipitation trends, the maize growing season precipitation trends show negative trends in the majority of the NCD and there were only 9 weather stations showing significant decreasing precipitation trends. It is noteworthy that Figure $7 \mathrm{~b}$ shows that most increased weather station was concentration in the Henan province. Figure 7c shows the nature and significance of the annual precipitation trends over the study area. There were 31 weather stations showing negative trends in annual precipitation, which is a total 
proportion of $57.4 \%$. Most of the weather station precipitations showed non-significant trends in the study region, with only one weather station showing dominant positive trends, and two showing dominant negative trends. The descriptive statistics for the precipitation trend when averaged for province-wide, funnel area, and regional are listed in Table 6. The magnitude of the wheat growing season precipitation trends was calculated as $6.94 \mathrm{~mm}$ per decade on the funnel area average basis, which was higher than the study region. Additionally, the precipitation trend was lower in the funnel area than in the regional basis for the maize growing season, which were -14.72 and $-9.63 \mathrm{~mm} / 10 \mathrm{a}$, respectively. All the provinces showed a positive trend for the wheat growing season and a negative trend for the maize growing season, with the Henan province being the only one out of the five provinces to show a positive trend for the annual precipitation. Table 6 shows that the annual precipitation decreased during the period of $1960-2015$ at a rate of -5.69 and $-2.98 \mathrm{~mm} / 10 \mathrm{a}$ in the funnel area and the regional basis, respectively.

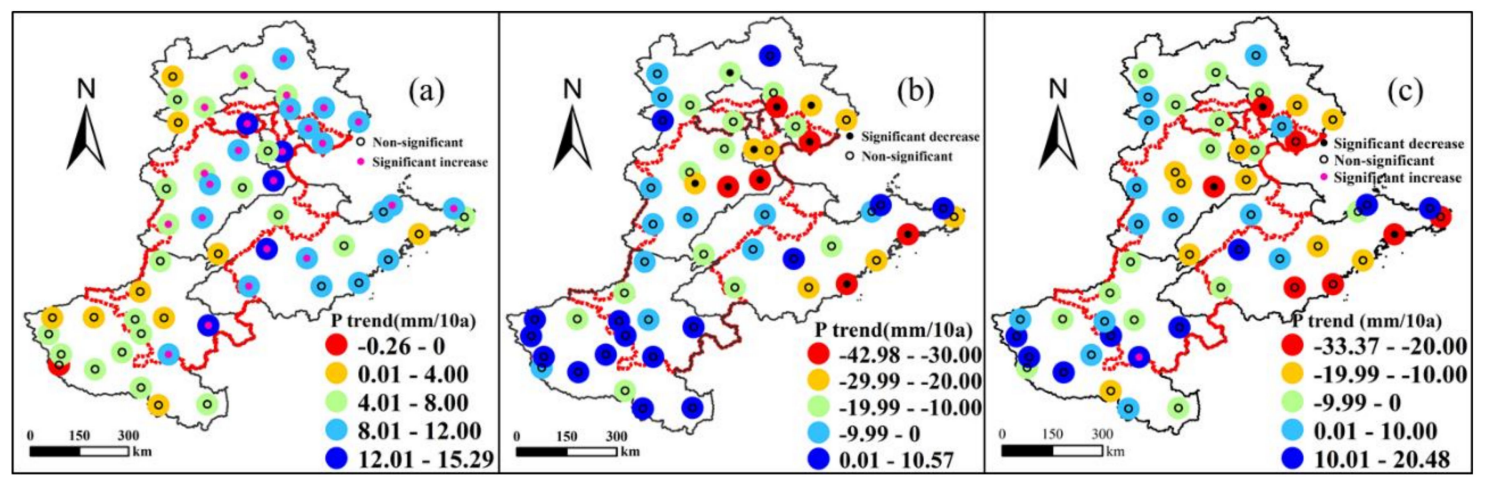

Figure 7. The spatial distribution and statistical significance of the trends in the precipitation $(\mathrm{P})$ of the (a) winter-wheat growing season; (b) the summer-maize growing season and (c) the annual basis.

Table 6. The province-wide, funnel area, and regional statistics for the wheat, maize, and annual precipitation average trend.

\begin{tabular}{cccccccc}
\hline $\mathbf{P}(\mathbf{m m} / \mathbf{1 0 a})$ & Beijing & Tianjin & Hebei & Henan & Shandong & Funnel Area & Regional \\
\hline Wheat growing season & $12.16^{*}$ & $8.46^{*}$ & $6.84^{*}$ & 4.01 & 6.69 & $6.94 *$ & $6.85^{*}$ \\
Maize growing season & -19.38 & $-20.53 *$ & $-17.32 *$ & -2.43 & -17.65 & $-14.72 *$ & $-9.63 *$ \\
Annual & -4.95 & -12.59 & -6.93 & 6.05 & -9.68 & -5.69 & -2.98 \\
\hline
\end{tabular}

${ }^{*}$ Indicates that the temporal trend is significant $(p<0.05)$.

\subsection{Spatial and Temporal Variation of Reference Evapotranspiration}

\subsubsection{Spatial Analysis}

$\mathrm{ET}_{0}$ is an important part of the hydrological cycle and occupies a more important proportion in the regional water resource balance. Different from the precipitation effects of the regional water resource supply, the $\mathrm{ET}_{0}$ mainly affects consumption, especially the crop water requirement. The results show that the mean winter-wheat growing season $\mathrm{ET}_{0}$ over a 56-year period varied from $420.3 \mathrm{~mm}$ to $670.0 \mathrm{~mm}$ across the NCD (Figure 8a). Averaged by province, the valley wheat growing season $\mathrm{ET}_{0}$ was observed in the Hebei province, which was $508.6 \mathrm{~mm}$ (Table 7), while the maximum values were observed in Beijing. The funnel area and regional $\mathrm{ET}_{0}$ were 545.9 and $531.2 \mathrm{~mm}$ for the wheat growing season. Figure $8 \mathrm{~b}$ shows that the central part of the $\mathrm{NCD} \mathrm{ET}_{0}$ was higher than the surrounding parts for the maize growing season. The average funnel area and regional maize growing season $\mathrm{ET}_{0}$ were 513.8 and $497.4 \mathrm{~mm}$, respectively, which was lower than that of the wheat growing season. The Jinan weather station had the maximum annual $\mathrm{ET}_{0}$, which was $1240.9 \mathrm{~mm}$. The annual $\mathrm{ET}_{0}$ from the lowest to the highest, province-wide, are as follows: Hebei, Henan, Shandong, Beijing, and Tianjin. 


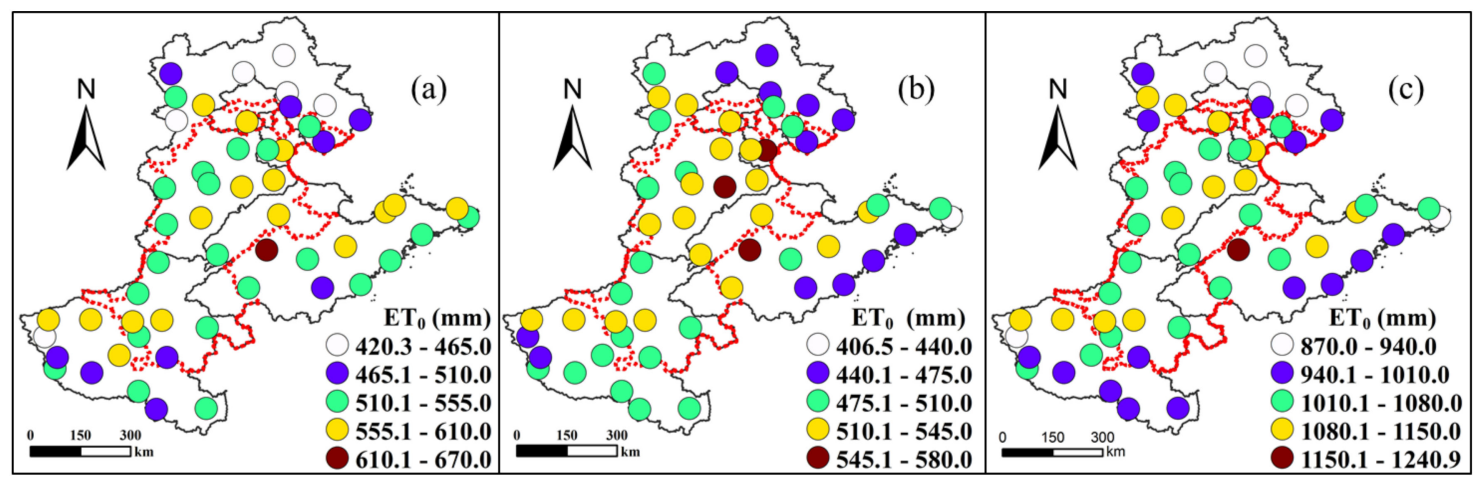

Figure 8. The spatial distribution of the long-term average reference evapotranspiration $\left(\mathrm{ET}_{0}\right)$ on $(\mathbf{a})$ the winter-wheat growing season; (b) the summer-maize growing season and (c) the annual basis.

Table 7. The province-wide, funnel area, and regional statistics for the wheat, maize, and annual average reference evapotranspiration.

\begin{tabular}{cccccccc}
\hline ET $_{\mathbf{0}}(\mathbf{m m})$ & Beijing & Tianjin & Hebei & Henan & Shandong & Funnel Area & Regional \\
\hline Wheat growing season & 571.2 & 569.3 & 508.6 & 531.9 & 552.8 & 545.9 & 531.2 \\
Maize growing season & 515.7 & 538.3 & 500.2 & 497.4 & 487.0 & 513.8 & 497.4 \\
Annual & 1086.9 & 1107.6 & 1008.8 & 1028.1 & 1032.0 & 1059.8 & 1026.1 \\
\hline
\end{tabular}

\subsubsection{Temporal Analysis}

The 61-year average of the $\mathrm{ET}_{0}$ trend in the research region and funnel area was about -0.53 and $-3.60 \mathrm{~mm} / 10 \mathrm{a}$ for the heat growing season (Table 8). The fluctuation range for the wheat growing season is from -15.62 to $15.61 \mathrm{~mm} / 10 \mathrm{a}$ (Figure 9a). There are 31 weather station $\mathrm{ET}_{0}$ that show negative trends for the wheat growing season and 15 of them show significant decreasing trends. Hebei is the only one of the five provinces that shows positive trends for the winter-wheat growing season $\mathrm{ET}_{0}$. The $\mathrm{ET}_{0}$ trends for the maize growing season show northeast to southwest decreasing trends. Only five weather station $\mathrm{ET}_{0}$ show positive trends for the maize growing season, which were all located in the east part of Shandong and the north part of Hebei. More than $68 \%$ of the weather stations show significant decreasing trends in the maize growing season. All five provincial (cities) $\mathrm{ET}_{0}$ show decreasing trends in the maize growing season. The annual $\mathrm{ET}_{0}$ trend ranges from -37.70 to $19.50 \mathrm{~mm} / 10 \mathrm{a}$ in the study area. The Tianjin, Hebei, Henan, and Shandong average $\mathrm{ET}_{0}$ trends show negative trends for the annual timescale, while Beijing shows positive trends. For the annual $\mathrm{ET}_{0}$, the funnel area and regional average trends were -17.49 and $-12.04 \mathrm{~mm} / 10 \mathrm{a}$, respectively.

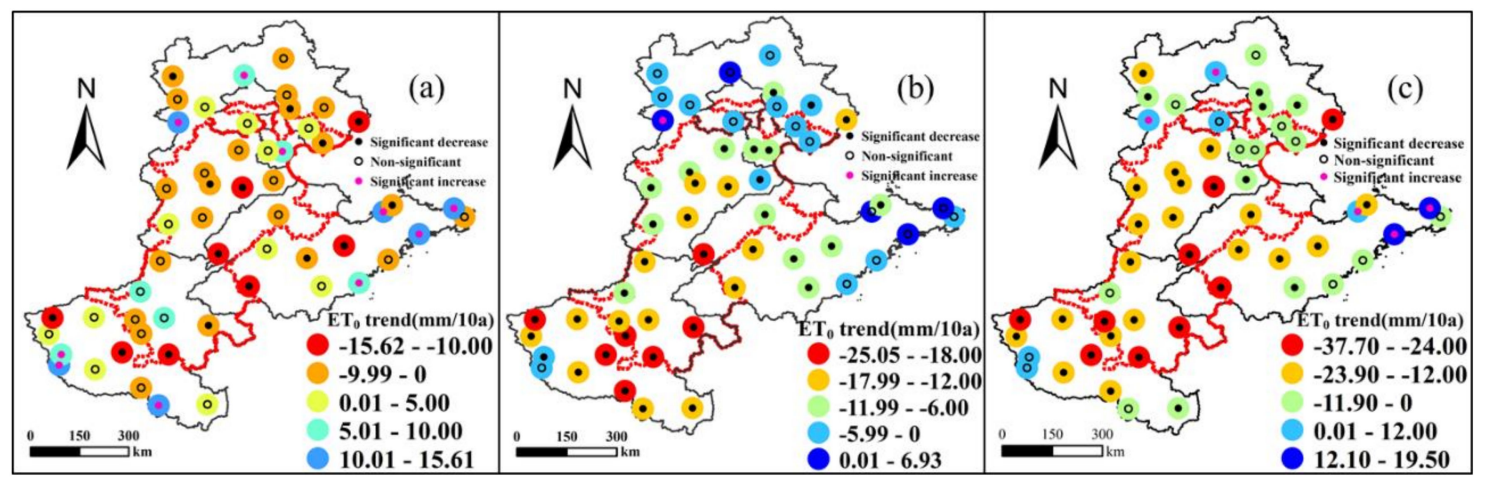

Figure 9. The spatial distribution and statistical significance of the trends in evapotranspiration $\left(\mathrm{ET}_{0}\right)$ on (a) the winter-wheat growing season, (b) the summer-maize growing season, and (c) the annual basis. 
Table 8. The province-wide, funnel area, and regional statistics for the wheat, maize, and annual average evapotranspiration trend.

\begin{tabular}{cccccccc}
\hline $\mathbf{E T}_{\mathbf{0}}(\mathbf{m m} / \mathbf{1 0 a})$ & Beijing & Tianjin & Hebei & Henan & Shandong & Funnel Area & Regional \\
\hline Wheat growing season & 4.54 & 2.96 & $-4.06^{*}$ & -0.85 & -3.07 & -5.24 & -2.44 \\
Maize growing season & -0.01 & $-9.58^{*}$ & $-6.32^{*}$ & $-15.71^{*}$ & $-7.12^{*}$ & $-11.35^{*}$ & $-8.85^{*}$ \\
Annual & 3.53 & -7.43 & $-10.73^{*}$ & $-17.44^{*}$ & $-10.58^{*}$ & $-17.49^{*}$ & $-12.04^{*}$ \\
\hline
\end{tabular}

${ }^{*}$ Indicates that the temporal trend is significant $(p<0.05)$.

\subsection{Spatial and Temporal Variation of Arid Index}

\subsubsection{Spatial Analysis}

$\mathrm{AI}$ is an index that combines precipitation with $\mathrm{ET}_{0}$, which can present information about drought or wetness in each district. AI is one of the most important indexes in meteorology, ecology, and agronomy, which is a widely used measure all over the world [48-50]. In this research, the aridity index was calculated at point locations for the wheat and maize growing seasons and the annual timescale. These calculations are presented in Figure 10. There were southeast-to-northwest decreasing trends in the AI. The descriptive statistics for the AI when averaged for the province-wide, funnel area, and regional bases are presented in Table 9. The AI for the wheat growing season had a great difference province-wide. The maximum AI was observed in Henan, while the valley AI occurred in Beijing. The average regional and funnel area wheat growing season AI are 0.26 and 0.34 , respectively, which means that the funnel area and the study area lie in the semi-arid class. For the maize growing season, the AI ranges from 0.55 to 1.30 (Figure 10b). The total study region falls into the humid class for the maize growing season, except the northwest part of the Hebei province. The regional average annual $\mathrm{AI}$ is 0.63 , which lies in the humid class. This does not mean that the region is dominantly humid, since we can find, in Figure 10c, that more than half of the study region lies in the semi-arid and dry sub-humid classes.

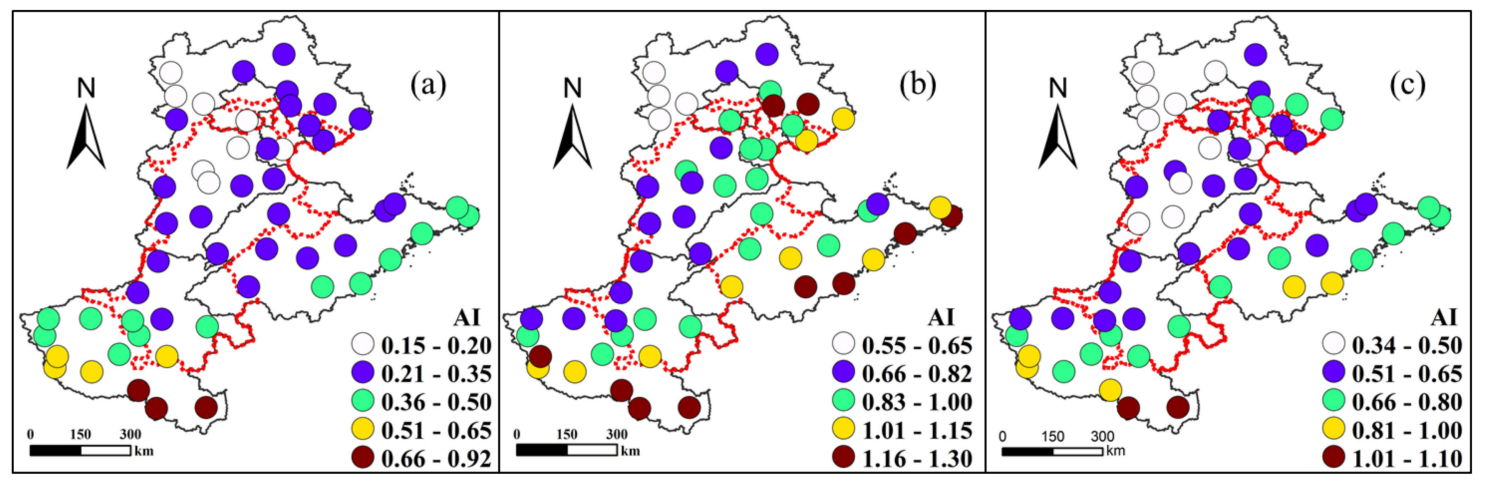

Figure 10. The spatial distribution of the long-term average aridity index on (a) the winter-wheat growing season; (b) the summer-maize growing season and (c) the annual basis.

Table 9. The province-wide, funnel area, and regional statistics for the wheat, maize, and annual average aridity indexes.

\begin{tabular}{cccccccc}
\hline AI & Beijing & Tianjin & Hebei & Henan & Shandong & Funnel Area & Regional \\
\hline Wheat growing season & 0.18 & 0.20 & 0.22 & 0.51 & 0.35 & 0.26 & 0.34 \\
Maize growing season & 0.88 & 0.83 & 0.84 & 0.97 & 1.08 & 0.86 & 0.95 \\
Annual & 0.51 & 0.50 & 0.52 & 0.73 & 0.68 & 0.55 & 0.63 \\
\hline
\end{tabular}




\subsubsection{Temporal Analysis}

The trends in the wheat and maize growing season AIs and the annual AI were calculated for each weather station in the study region. Figure 11 shows the wheat and maize growing season AIs and the annual AI by the M-K test for each weather station between 1960 and 2015. The wheat growing season $\mathrm{AI}$ has decreased over most of the study region, with 49 weather station AI showing an increasing trend in the wheat growing season, 21 of which were significantly increasing. For the maize growing season $\mathrm{AI}$, about $57 \%$ of the weather stations had negative trends and most of the weather stations are concentrated in the west part of Shandong and the north part of the Jing-Jin-Ji region. The average regional wheat and maize growing season AI trends are 0.013 and $-0.004 / 10 \mathrm{a}$. There are 7 weather station AIs that show increasing trends for the annual timescale and all of them are in the Henan province. So, the only province with increasing trends in annual AI was observed in Henan (Table 10). The funnel area and regional annual AI show slight decreasing trends, which were 0.004 and $0.005 / 10 a$, respectively.

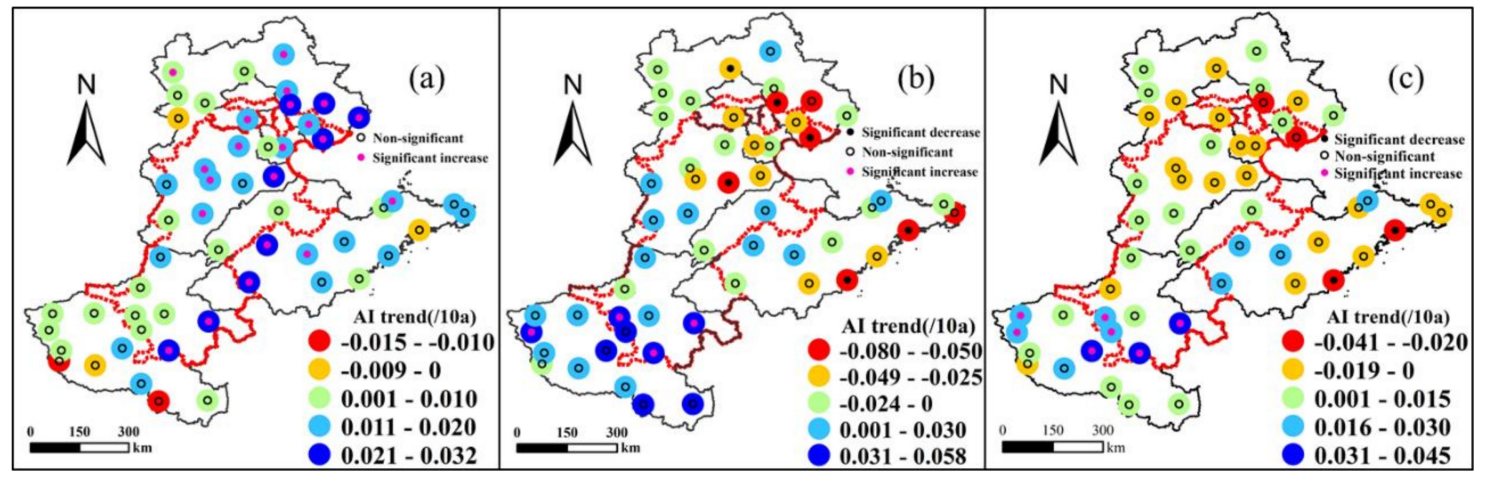

Figure 11. The spatial distribution and statistical significance of the trends in the aridity index on (a) the winter-wheat growing season; (b) the summer-maize growing season and (c) the annual basis.

Table 10. Province-wide, funnel area and regional statistics for wheat, maize, and annual average aridity index trend.

\begin{tabular}{cccccccc}
\hline AI (/10a) & Beijing & Tianjin & Hebei & Henan & Shandong & Funnel Area & Regional \\
\hline Wheat growing season & $0.019^{*}$ & $0.013^{*}$ & $0.015^{*}$ & 0.008 & 0.013 & $0.016^{*}$ & $0.013^{*}$ \\
Maize growing season & -0.04 & -0.025 & -0.024 & 0.024 & -0.027 & -0.008 & -0.004 \\
Annual & -0.009 & -0.008 & 0.000 & 0.017 & -0.005 & 0.004 & 0.005 \\
\hline
\end{tabular}

${ }^{*}$ Indicates that the temporal trend is significant $(p<0.05)$.

\section{Discussion}

\subsection{Perspectives and Implications}

Due to the rising population, dietary changes, and increasing biofuel consumption, crop production must be doubled to meet the coming global food demand [51]. On the other hand, for most of the world, groundwater must be pumped for irrigation purposes in order to maintain a high yield, especially in semi-arid and arid regions [52]. Irrigation has led to the rapid decline of the groundwater table in highly intensified agricultural parts of the world, such as the North China Plain, the Sanjiang Plain, the Central Valley of California, and the Indus River Basin [52,53]. Water shortages have become the main factor limiting grain production in the world, as well as NCD, since the cropping system has changed from one rainfed crop to the winter wheat-summer maize system of irrigation and since the NPD's grain production has increased and become one of the major grain producing areas in China, while the groundwater table was declined rapidly at the same time [47,54]. Meteorological elements have strong effects on crop yields and water consumption [2] and agricultural water accounts 
for $62.4 \%$ of the total water usage in the NCD [55]. Thus, evaluating meteorological element changes both spatially and temporally is meaningful for us to understand the possible effects of climate change on the NCD's water and food security.

\subsection{Influence of Climate Factors on Regional Water Security}

The current results showed that the spatial variations of $\mathrm{ET}_{0}$ and precipitation were quite different in the wheat and maize growing seasons and the annual timescale. The average precipitation decreasing trend from the northwest to southeast and the average $\mathrm{ET}_{0}$ show decreasing trends from the central part of the NCD to the surroundings, which lead to the funnel area AI being lower than other parts of the NCD. Similar results have been found by Fan et al. [56]. Precipitation and irrigation are the only two ways to meet the crop water requirement in the NCD. Lesser precipitation and more evapotranspiration meant that more irrigation from groundwater is needed for agriculture. There was one cropping system in the north part of the Hebei province because of the low temperature in winter, while the other was a double cropping system. The double cropping system and lesser precipitation led to the agriculture of the funnel area needing more groundwater for irrigation in order to maintain a high yield level. Over pumping the region's groundwater resources over the past three decades may have caused a cone of depression in the groundwater table (funnel area).

Our results show that the regional mean annual precipitation was $632.9 \mathrm{~mm}$ and more than $70 \%$ occurred during the summer maize growing season, while there was little difference for the $\mathrm{ET}_{0}$ between the wheat growing season and the maize growing season. This means that more irrigation was needed in the wheat growing season. Rainfall can meet the maize water requirement for the most part of the NCD [57]. In order to protect the groundwater resources, sustainable farmland use must be maintained and agricultural sustainable development must be forwarded. China has been developing a reasonable subsidy policy of cultivated land fallow by selecting some areas as pilot areas in the funnel area since 2016. The fallow policy changed double cropping back to one rainfed crop system with a winter fallow, which will greatly reduce the groundwater resource consumption in the funnel area. This study indicates that the precipitation for the wheat growing season showed an increasing trend in the funnel area (Table 6), while the $\mathrm{ET}_{0}$ showed a decreasing trend (Table 8). More precipitation and fewer water requirements mean that less irrigation was needed for the wheat growing season. The precipitation and the $\mathrm{ET}_{0}$ for the maize growing season both showed decreasing trends in the funnel area and the AI showed decreasing trends as well. This indicates that more groundwater must be pumped to maintain an optimal yield for the maize growing season. If the climate changing trend in the future was the same as in the past, the decreasing AI will enhance the water deficit and drought risk for the rainfed maize. Though the precipitation for wheat shows a positive trend, the winter fallow policy will waste more precipitation as weed evapotranspiration. The annual precipitation showed a slightly decreasing trend regional, while the $\mathrm{ET}_{0}$ showed a decreasing trend too, so the annual AI showed a slightly positive trend. Discarding the fallow policy, climate change has had positive impacts on the regional water security. On the other hand, the South-to-North Water Diversion Project will ultimately transfer $44.8 \mathrm{Gm}^{3}$ water from the Yangtze River Basin to NCD annually, which will greatly release the water stress of the NCD.

\subsection{Effects of Climate Factors on Regional and National Food Security}

The crop yield is mainly affected by solar radiation and temperature. A lot of evidence is available, showing the importance and the positive effect of solar radiation on the grain yield $[9,58-60]$. Stanhill [61] reported a globally average solar radiation reduction of $0.43 \mathrm{MJ} / \mathrm{day} / \mathrm{m}^{2}$ per decade, which was lower than the NCD average reduction. The negative trend of solar radiation has been and will be an increasing challenge for NCD's crop production.

The observed changes in temperature in NCD were in line with other research (Fan et al., 2016; Yuan et al., 2010; Tao and Zhao, 2010). Zhao et al. [62] reported that the global production of wheat declined by $6.0 \%$ and maize by $7.4 \%$ for each $1{ }^{\circ} \mathrm{C}$ increase in the global mean temperature. 
Peng et al. [45] suggested that each degree-Celsius increase in the growing season minimum temperature would reduce $10 \%$ of the grain yield. The current results indicated that both $\mathrm{T}_{\min }$ showed significant increasing trends for the wheat and maize growing seasons in most of the NCD (Figure 3). Table 2 showed that the regional wheat $\mathrm{T}_{\min }$ trend was $0.44^{\circ} \mathrm{C} / 10 \mathrm{a}$, which was a little higher than the value of $0.037^{\circ} \mathrm{C} /$ a calculated by Fan et al. [56] for the whole nation. The trend of $\mathrm{T}_{\min }$ leads the wheat yield of the NCD to decline by about $0.44 \%$ per year by the Peng's [39] results, discarding agronomic (variety and management practices) factor changes that occurred. When the $\mathrm{T}_{\max }$ was under $30^{\circ} \mathrm{C}$, the higher the $\mathrm{T}_{\max }$, the more yield obtained. Once the $\mathrm{T}_{\max }>30^{\circ} \mathrm{C}$, which was defined as a high temperature by Schauberger [44], the crop enzymes and tissues are damaged $[63,64]$ and the temperature impairs flowering [65], leads to precocious maturity and senescence [66], and triggers oxidative stress [67]. So, crop yields decline rapidly due to high temperatures, especially under rainfed conditions $[4,6,44]$. Figure $2 \mathrm{e}$ showed that the average $\mathrm{T}_{\max }$ for the maize growing season was over $30{ }^{\circ} \mathrm{C}$ in the central part of the NCD, which indicates that $\mathrm{T}_{\max }$ has a negative impact on the maize yield in this area. The best temperature for wheat anthesis and grain filling ranges from 12 to $22^{\circ} \mathrm{C}$ [68]. The wheat growing season $\mathrm{T}_{\max }$ was shown to have an increasing trend for all parts of the NCD, which can lead to the early maturation of wheat and the significant reduction of the wheat yield $[69,70]$.

The increasing temperatures have led to the north boundary of the two-crop area moving north $[41,71]$, which means that the two-crop area has increased in the NCD. This would relieve the pressures of food security of the NCD, but, on the other hand, it would increase the area that over-exploits the groundwater of the NCD. In addition, the fallow policy has reduced the agricultural groundwater consumption by reducing the winter wheat planted area. To maintain the province-wide crop production, the non-funnel area has changed from the cotton to the winter wheat-summer maize cropping system [72]. So, the wheat planted area did not change very much for the whole NCD, while the wheat planted area has increased in the non-funnel area, which will decrease the groundwater table of the non-funnel area.

\section{Conclusions}

The long-term wheat and maize growing season and the annual average air temperatures $\left(\mathrm{T}_{\min }, \mathrm{T}_{\max }\right)$ showed strong north to south increasing trends throughout the NCD, with exceptionally lower temperatures observed in the west part of the Henan province with high elevation. The average daily solar radiation was higher in the north compared with that of the south for the wheat and maize growing seasons and the annual timescale, which had ranges of 12.5-14.9, 16.7-19.6, and 14.3-16.5 MJ $/$ day $/ \mathrm{m}^{2}$, respectively. The average precipitation decreased from the northwest to the southeast in each growing season and annual timescale. The funnel area annual precipitation, mainly located in the Hebei province, was $570.4 \mathrm{~mm}$, which was lower than the regional average precipitation. While the funnel $\mathrm{ET}_{0}$ was higher than the regional average $\mathrm{ET}_{0}$. Therefore, the $\mathrm{AI}$, as a result of the magnitudes of both the precipitation and the $\mathrm{ET}_{0}$, was lower in the funnel area than in the regional area. The high $\mathrm{ET}_{0}$, low rainfall, and double cropping system may cause the world's largest mining of the groundwater funnel area. The historical spatial datasets were constructed, presented, and analyzed in this research can aid water and environmental personnel, water resource researchers, and policymaking agencies better understand the variations of the NCD climate and provide a theoretical basis for it. The trend for the wheat growing season was larger than that of the maize growing season. The solar radiation was shown to have a decreasing trend for both the wheat and maize growing seasons. The increasing trend of $\mathrm{T}_{\min }$ and the decreasing trend of the solar radiation may reduce crop production. The funnel area AI showed increasing trends for the winter wheat growing season and decreasing trends for the maize growing season. Though the winter fallow policy reduced the groundwater pumping, the increasing precipitation trend of the winter wheat growing season would cause a wastage of water by soil water evaporation. Climate change has had positive impacts on the NCD's water security, especially for the funnel area, as shown by the increasing trend of the annual AI. 
Author Contributions: Y.Y.; L.P. and Y.J. collected the data. J.T. and J.L. analyzed the data; J.T. and X.Y. wrote the paper. X.W. and F.C. edited the paper.

Funding: This research was funded by [National Key Research and Development Program of China] grant number [2016YFD0300201].

Acknowledgments: This study was financially supported by the National Key Research and Development Program of China (2016YFD0300201). We thank the anonymous reviewers and the Editor for their suggestions, which substantially improved the manuscript.

Conflicts of Interest: The authors declare no conflict of interest.

\section{References}

1. Intergovernmental Panel on Climate Change (IPCC). Climate Change 2013: The Physical Science Basis. Contribution of Working Group I to the Fifth Assessment Report of the Intergovernmental Panel on Climate Change; Cambridge University Press: Cambridge, UK, 2013.

2. Rosenzweig, C.; Elliott, J.; Deryng, D.; Ruane, A.C.; Müller, C.; Arneth, A.; Boote, K.J.; Folberth, C.; Glotter, M.; Khabarov, N.; et al. Assessing Agricultural Risks of Climate Change in the 21st Century in a Global Gridded Crop Model Intercomparison. Proc. Natl. Acad. Sci. USA 2014, 111, 3268-3273. [CrossRef] [PubMed]

3. Wheeler, T.; Von Braun, J. Climate Change Impacts on Global Food Security. Science 2013, 341, 508-513. [CrossRef] [PubMed]

4. Challinor, A.J.; Watson, J.; Lobell, D.B.; Howden, S.M.; Smith, D.R.; Chhetri, N. A Meta-Analysis of Crop Yield under Climate Change and Adaptation. Nat. Clim. Chang. 2014, 4, 287-291. [CrossRef]

5. Kang, Y.; Khan, S.; Ma, X. Climate Change Impacts on Crop Yield, Crop Water Productivity and Food Security-A Review. Prog. Nat. Sci. 2009, 19, 1665-1674. [CrossRef]

6. O’Leary, G.J.; Aggarwal, P.K.; Calderini, D.F.; Connor, D.J.; Craufurd, P.; Eigenbrode, S.D.; Han, X.; Hatfield, J.L. Challenges and Responses to Ongoing and Projected Climate Change for Dryland Cereal Production Systems throughout the World. Agronomy 2018, 8, 34. [CrossRef]

7. Holzkämper, A. Adapting Agricultural Production Systems to Climate Change-What's the Use of Models? Agriculture 2017, 7, 86. [CrossRef]

8. Schlenker, W.; Roberts, M.J. Nonlinear Temperature Effects Indicate Severe Damages to U.S. Crop Yields under Climate Change. Proc. Natl. Acad. Sci. USA 2009, 106, 15594-15598. [CrossRef] [PubMed]

9. Fischer, G.; Tubiello, F.N.; Van Velthuizen, H.; Wiberg, D.A. Climate Change Impacts on Irrigation Water Requirements: Effects of Mitigation, 1990-2080. Technol. Forecast. Soc. Chang. 2007, 74, 1083-1107. [CrossRef]

10. National Bureau of Statistics of China. China Statistical Yearbook 2017; China Statistics Press: Beijing, China, 2017.

11. Sun, H.; Zhang, X.; Wang, E.; Chen, S.; Shao, L. Quantifying the Impact of Irrigation on Groundwater Reserve and Crop Production-A Case Study in the North China Plain. Eur. J. Agron. 2015, 70, 48-56. [CrossRef]

12. Yang, X.L.; Chen, Y.Q.; Steenhuis, T.S.; Pacenka, S.; Gao, W.S.; Ma, L.; Zhang, M.; Sui, P. Mitigating Groundwater Depletion in North China Plain with Cropping System That Alternate Deep and Shallow Rooted Crops. Front. Plant Sci. 2017, 8, 980. [CrossRef] [PubMed]

13. Bale, J.S.; Masters, G.J.; Hodkinson, I.D.; Awmack, C.; Bezemer, T.M.; Brown, V.K.; Butterfield, J.; Buse, A.; Coulson, J.C.; Farrar, J.; et al. Herbivory in Global Climate Change Research: Direct Effects of Rising Temperature on Insect Herbivores. Glob. Chang. Biol. 2002, 8, 1-16. [CrossRef]

14. Dai, A.; Fyfe, J.C.; Xie, S.P.; Dai, X. Decadal Modulation of Global Surface Temperature by Internal Climate Variability. Nat. Clim. Chang. 2015, 5, 555-559. [CrossRef]

15. Morice, C.P.; Kennedy, J.J.; Rayner, N.A.; Jones, P.D. Quantifying Uncertainties in Global and Regional Temperature Change Using an Ensemble of Observational Estimates: The Hadcrut4 Data Set. J. Geophys. Res. Atmos. 2012, 117. [CrossRef]

16. Liepert, B.G. Observed Reductions of Surface Solar Radiation at Sites in the United States and Worldwide from 1961 to 1990. Geophys. Res. Lett. 2002, 29, 61-1-61-4. [CrossRef]

17. Alexander, L.V.; Zhang, X.; Peterson, T.C.; Caesar, J.; Gleason, B.; Klein Tank, A.M.G.; Haylock, M.; Collins, D.; Trewin, B.; Rahimzadeh, F.; et al. Global Observed Changes in Daily Climate Extremes of Temperature and Precipitation. J. Geophys. Res. Atmos. 2006, 111. [CrossRef]

18. Arnell, N.W. Climate Change and Global Water Resources. Glob. Environ. Chang. 1999, 9, S31-S49. [CrossRef] 
19. Gorelick, S.M.; Zheng, C. Global Change and the Groundwater Management Challenge. Water Resour. Res. 2015, 51, 3031-3051. [CrossRef]

20. Huang, J.; Yu, H.; Guan, X.; Wang, G.; Guo, R. Accelerated Dryland Expansion under Climate change. Nat. Clim. Chang. 2015, 6, 166-171. [CrossRef]

21. Zarch, M.A.A.; Sivakumar, B.; Sharma, A. Assessment of Global Aridity Change. J. Hydrol. 2015, 520, 300-313. [CrossRef]

22. Cao, G.; Han, D.; Song, X. Evaluating Actual Evapotranspiration and Impacts of Groundwater Storage Change in the North China Plain. Hydrol. Process. 2014, 28, 1797-1808. [CrossRef]

23. Hargreaves, G.H.; Samani, Z.A. Estimating Potential Evapotranspiration. J. Irrig. Drain. Div. 1982, 108, 225-230.

24. Priestley, C.H.B.; Taylor, R.J. On the Assessment of Surface Heat Flux and Evaporation Using Large-Scale Parameters. Mon. Weather Rev. 1972, 100, 81-92. [CrossRef]

25. Penman, H.L. Natural Evaporation from Open Water, Bare Soil and Grass. Proc. R. Soc. Lond. Ser. A Math. Phys. Eng. Sci. 1948, 193, 120-145. [CrossRef]

26. Frere, M.; Popov, G.F. Agrometeorological Crop Monitoring and Forecasting; FAO: Rome, Italy, 1979.

27. Rietveld, M.R. A New Method for Estimating the Regression Coefficients in the Formula Relating Solar Radiation to Sunshine. Agric. Meteorol. 1978, 19, 243-252. [CrossRef]

28. Snyder, R.L.; Orang, M.N.; Matyac, S.G.J.S.; Sarreshteh, S. Simetaw (Simulation of Evapotranspiration of Applied Water). In California Water Plan Update; Department of Water Resources: Sacramento, CA, USA, 2005.

29. Yang, X.; Gao, W.; Shi, Q.; Chen, F.; Chu, Q. Impact of Climate Change on the Water Requirement of Summer Maize in the Huang-Huai-Hai Farming Region. Agric. Water Manag. 2013, 124, 20-27. [CrossRef]

30. Yang, X.L.; Song, Z.W.; Wang, H.; Shi, Q.H.; Chen, F.; Chu, Q.Q. Spatio-Temporal Variations of Winter-Wheat Water Requirement and Climatic Causes in Huang-Huai-Hai Farming Region. Chin. J. Eco-Agric. 2012, 20, 356-362. [CrossRef]

31. Song, Z.W. Construction of the Water-Saving Cropping Patterns Based on Simulation Model and Scenario Analysis: A Case of Beijing; China Agricultural University: Beijing, China, 2009.

32. Huang, J.; Xu, C.; Ridoutt, B.G.; Chen, F. Reducing Agricultural Water Footprints at the Farm Scale: A Case Study in the Beijing Region. Water 2015, 7, 7066-7077. [CrossRef]

33. United Nations Educational, Scientific and Cultural Organization (UNESCO). Map of the World Distribution of Arid Regions: Map at Scale 1:25,000,000 with Explanatory Note; MAB Technical Notes; UNESCO: Paris, France, 1979.

34. Mann, H.B. Nonparametric Tests against Trend. Econometrica 1945, 13, 245-259. [CrossRef]

35. Kendall, M.G.; Stuart, A. The Advanced Theory of Statistics; Griffin: London, UK, 1946; Volume 3.

36. Shadmani, M.; Marofi, S.; Roknian, M. Trend analysis in reference evapotranspiration using Mann-Kendall and Spearman's Rho tests in arid regions of Iran. Water Resour. Manag. 2012, 26, 211-224. [CrossRef]

37. Yue, S.; Pilon, P.; Cavadias, G. Power of the Mann-Kendall and Spearman's rho tests for detecting monotonic trends in hydrological series. J. Hydrol. 2002, 259, 254-271. [CrossRef]

38. Ahmad, I.; Tang, D.; Wang, T.; Wang, M.; Wagan, B. Precipitation trends over time using Mann-Kendall and spearman's rho tests in swat river basin, Pakistan. Adv. Meteorol. 2015, 431860. [CrossRef]

39. Kundzewicz, Z.W.; Robson, A.J. Detecting Trend and other Changes in Hydrological Data. World Climate Programme-Water, World Climate Programme Data and Monitoring, WCDMP-45, WMO/TD no. 1013; World Meteorological Organization: Geneva, Switzerland, 2000.

40. Sen, P.K. Estimates of the Regression Coefficient Based on Kendall's Tau. J. Am. Stat. Assoc. 1968, 63, $1379-1389$. [CrossRef]

41. Li, W.J.; Liang, H.; Wang, P.J. Effects of Climate Warming on the Planting Boundary and Developmental Stages of Winter Wheat. J. Triticeae Crops 2013, 33, 382-388.

42. Wang, Z.B.; Wang, M.; Yin, X.G.; Zhang, H.L.; Chu, Q.Q.; Wen, X.Y.; Chen, F. Spatiotemporal Change Characteristics of Heat and Rainfall during the Growth Period of Summer Maize in North China Plain from 1961 to 2010. Chin. J. Eco-Agric. 2015, 23, 473-481.

43. Wang, Z.B.; Wang, M.; Yin, X.G.; Zhang, H.L.; Chu, Q.Q. Spatiotemporal Change Characteristics of Heat and Rainfall during the Growth Period of Winter Wheat in North China Plain from 1961 to 2010. J. China Agric. Univ. 2015, 20, 16-23. 
44. Schauberger, B.; Archontoulis, S.; Arneth, A.; Balkovic, J.; Ciais, P.; Deryng, D.; Elliott, J.; Folberth, C.; Khabarov, N.; Müller, C.; et al. Consistent Negative Response of Us Crops to High Temperatures in Observations and Crop Models. Nat. Commun. 2017, 8, 13931. [CrossRef] [PubMed]

45. Peng, S.; Huang, J.; Sheehy, J.E.; Laza, R.C.; Visperas, R.M.; Zhong, X.; Centeno, G.S.; Khush, G.S.; Cassman, K.G. Rice Yields Decline with Higher Night Temperature from Global Warming. Proc. Natl. Acad. Sci. USA 2004, 101, 9971-9975. [CrossRef] [PubMed]

46. Wang, Z.; Xie, P.; Lai, C.; Chen, X.; Wu, X.; Zeng, Z.; Li, J. Spatiotemporal Variability of Reference Evapotranspiration and Contributing Climatic Factors in China during 1961-2013. J. Hydrol. 2017, 544, 97-108. [CrossRef]

47. Kong, X.; Zhang, X.; Lal, R.; Zhang, F.; Chen, X.; Niu, Z.; Han, L.; Song, W. Groundwater Depletion by Agricultural Intensification in China's Hhh Plains, since 1980s. In Advances in Agronomy; Academic Press: Cambridge, MA, USA, 2015.

48. Xiao, D.; Tao, F.; Liu, Y.; Shi, W.; Wang, M.; Liu, F.; Zhang, S.; Zhu, Z. Observed Changes in Winter Wheat Phenology in the North China Plain for 1981-2009. Int. J. Biometeorol. 2012, 57, 275-285. [CrossRef] [PubMed]

49. Nastos, P.T.; Politi, N.; Kapsomenakis, J. Spatial and Temporal Variability of the Aridity Index in Greece. Atmos. Res. 2013, 119, 140-152. [CrossRef]

50. Yin, X.; Olesen, J.E.; Wang, M.; Kersebaum, K.C.; Chen, H.; Baby, S.; Öztürk, I.; Chen, F. Adapting Maize Production to Drought in the Northeast Farming Region of China. Eur. J. Agron. 2016, 77, 47-58. [CrossRef]

51. Ray, D.K.; Mueller, N.D.; West, P.C.; Foley, J.A. Yield Trends Are Insufficient to Double Global Crop Production by 2050. PLoS ONE 2013, 8, e66428. [CrossRef] [PubMed]

52. Aeschbach-Hertig, W.; Gleeson, T. Regional Strategies for the Accelerating Global Problem of Groundwater Depletion. Nat. Geosci. 2012, 5, 853-861. [CrossRef]

53. Rodell, M.; Velicogna, I.; Famiglietti, J.S. Satellite-Based Estimates of Groundwater Depletion in India. Nature 2009, 460, 999-1002. [CrossRef] [PubMed]

54. Liu, Y.; Wang, E.; Yang, X.; Wang, J. Contributions of Climatic and Crop Varietal Changes to Crop Production in the North China Plain, since 1980s. Glob. Chang. Biol. 2009, 16, 2287-2299. [CrossRef]

55. Bureau of Provincial Water Resources. Water Resource Bulletin; China Water Power Press: Beijing, China, 2014.

56. Fan, J.; Wu, L.; Zhang, F.; Xiang, Y.; Zheng, J. Climate Change Effects on Reference Crop Evapotranspiration across Different Climatic Zones of China during 1956-2015. J. Hydrol. 2016, 542, 923-937. [CrossRef]

57. Zhang, X.; Chen, S.; Sun, H.; Shao, L.; Wang, Y. Changes in Evapotranspiration over Irrigated Winter Wheat and Maize in North China Plain over Three Decades. Agric. Water Manag. 2011, 98, 1097-1104. [CrossRef]

58. Muchow, R.C.; Sinclair, T.R.; Bennett, J.M. Temperature and Solar Radiation Effects on Potential Maize Yield across Locations. Agron. J. 1990, 82, 338-343. [CrossRef]

59. Cossu, M.; Murgia, L.; Ledda, L.; Deligios, P.A.; Sirigu, A.; Chessa, F.; Pazzona, A. Solar Radiation Distribution inside a Greenhouse with South-Oriented Photovoltaic Roofs and Effects on Crop Productivity. Appl. Energy 2014, 133, 89-100. [CrossRef]

60. Wang, J.; Dong, J.; Yi, Y.; Lu, G.; Oyler, J.; Smith, W.K.; Zhao, M.; Liu, J.; Running, S. Decreasing Net Primary Production Due to Drought and Slight Decreases in Solar Radiation in China from 2000 to 2012. J. Geophys. Res. Biogeosci. 2017, 122, 261-278. [CrossRef]

61. Stanhill, G.; Cohen, S. Global Dimming: A Review of the Evidence for a Widespread and Significant Reduction in Global Radiation with Discussion of Its Probable Causes and Possible Agricultural Consequences. Agric. For. Meteorol. 2001, 107, 255-278. [CrossRef]

62. Zhao, C.; Liu, B.; Piao, S.; Wang, X.; Lobell, D.B.; Huang, Y.; Huang, M.; Yao, Y.; Bassu, S.; Ciais, P.; et al. Temperature Increase Reduces Global Yields of Major Crops in Four Independent Estimates. Proc. Natl. Acad. Sci. USA 2017, 114, 9326-9331. [CrossRef] [PubMed]

63. Farooq, M.; Wahid, A.; Kobayashi, N.; Fujita, D.; Basra, S.M.A. Plant Drought Stress: Effects, Mechanisms and Management. In Sustainable Agriculture; Springer: Dordrecht, the Netherlands, 2009.

64. Hasanuzzaman, M.; Nahar, K.; Alam, M.M.; Roychowdhury, R.; Fujita, M. Physiological, Biochemical, and Molecular Mechanisms of Heat Stress Tolerance in Plants. Int. J. Mol. Sci. 2013, 14, 9643-9684. [CrossRef] [PubMed]

65. Boyer, J.S.; Westgate, M.E. Grain Yields with Limited Water. J. Exp. Bot. 2004, 55, 2385-2394. [CrossRef] [PubMed] 
66. Folberth, C.; Yang, H.; Gaiser, T.; Liu, J.; Wang, X.; Williams, J.; Schulin, R. Effects of Ecological and Conventional Agricultural Intensification Practices on Maize Yields in Sub-Saharan Africa under Potential Climate Change. Environ. Res. Lett. 2014, 9, 044004. [CrossRef]

67. Kadam, N.N.; Xiao, G.; Melgar, R.J.; Bahuguna, R.N.; Quinones, C.; Tamilselvan, A.; Prasad, P.V.V.; Jagadish, K.S. Chapter Three-Agronomic and Physiological Responses to High Temperature, Drought, and Elevated $\mathrm{CO}_{2}$ Interactions in Cereals. Adv. Agron. 2014, 127, 111-156.

68. Farooq, M.; Bramley, H.; Palta, J.A.; Siddique, K.H. Heat Stress in Wheat during Reproductive and Grain-Filling Phases. Crit. Rev. Plant Sci. 2011, 30, 491-507. [CrossRef]

69. Tewolde, H.; Fernandez, C.J.; Erickson, C.A. Wheat Cultivars Adapted to Post-Heading High Temperature Stress. J. Agron. Crop Sci. 2006, 192, 111-120. [CrossRef]

70. Mondal, S.; Joshi, A.K.; Huerta-Espino, J.; Singh, R.P. Early Maturity in Wheat for Adaptation to High Temperature Stress. In Advances in Wheat Genetics: From Genome to Field; Springer: Tokyo, Japan, 2015.

71. Li, K.N.; Yang, X.G.; Liu, Z.J.; Wang, W.F.; Chen, F. Analysis of the Potential Influence of Global Climate Change on Cropping Systems in China III. The Change Characteristics of Climatic Resources in Northern China and Its Potential Influence on Cropping Systems. Sci. Agric. Sin. 2010, 43, 2088-2097.

72. Hebei Province Bureau of Statistics. Hebei Statistical Yearbook 2016; China Statistics Press: Beijing, China, 2016.

(c) 2018 by the authors. Licensee MDPI, Basel, Switzerland. This article is an open access article distributed under the terms and conditions of the Creative Commons Attribution (CC BY) license (http://creativecommons.org/licenses/by/4.0/). 